\title{
Effect of Non-conventional Chemicals and Synthetic Fungicide on Biochemical Characteristics of Chilli against Fruit Rot Pathogen Colletotrichum capsici
}

\author{
Neelam Geat ${ }^{1,2 *}$, Devendra Singh $^{3}$ and SK Khirbat ${ }^{1}$ \\ ${ }^{1}$ Department of Plant Pathology, CCS Haryana Agricultural University, Hisar (125004), Haryana, India \\ ${ }^{2}$ Division of Plant Pathology, Indian Agricultural Research Institute, New Delhi (110012), India \\ ${ }^{3}$ Division of Microbiology, Indian Agricultural Research Institute, New Delhi (110012), India
}

\begin{abstract}
A pot experiment was conducted during 2013-14 at Chaudhary Charan Singh, Haryana Agricultural University, Hisar to evaluate the effect of non-conventional chemical viz., salicylic acid, zinc sulphate, magnesium sulphate, indole acetic acid, indole butyric acid and fungicide viz., carbendazim, on total phenol, flavonol, tannin and electrolyte leakage of red fruits of chilli varieties (susceptible-Pusa Jwala and resistant-Sadabahar) against Colletotrichum capsici the causal agent of fruit rot in chilli. The phenol content was increased significantly in both the varieties (resistant and susceptible) when sprayed with salicylic acid followed by pathogen as compared to other non-conventional chemicals at 24 and 48 hrs intervals. The increase in total phenol was more pronounced in resistant variety $(7.84$ $\mathrm{mg} / \mathrm{g}$ fresh weight) after $48 \mathrm{hrs}$, when sprayed with salicylic acid at $5 \mathrm{mM}$ concentration. Flavonol content was higher in uninoculated red fruits of susceptible variety $(1.50 \mathrm{mg} / \mathrm{g}$ fresh weight) as compared to resistant $(1.37 \mathrm{mg} / \mathrm{g}$ fresh weight). Tannin content was higher in resistant $(3.71 \mathrm{mg} / \mathrm{g}$ fresh weight) as well as susceptible $(3.09 \mathrm{mg} / \mathrm{g}$ fresh weight) varieties after inoculation than uninoculated varieties (1.38 and $1.02 \mathrm{mg} / \mathrm{g}$ fresh weight, respectively) at 5 $\mathrm{mM}$ concentration. The activity of electrolytes was more pronounced in resistant variety as compared to susceptible variety when sprayed with non-conventional and fungicide in all the concentration. Electrolytes leakage was more when sprayed with fungicide as compared with salicylic acid $5 \mathrm{mM}$ concentration after $48 \mathrm{hrs}$ of pathogen inoculation.
\end{abstract}

Keywords: Chilli; Colletotrichum capsici; Electrolyte leakage; Flavonol; Non-conventional; Phenol; Resistant; Salicylic acid and tannin

\section{Introduction}

Among the major diseases of chilli, fruit rot caused by Colletotrichum capsici is one of the major disease in the production of chilli. The disease causes severe damage on red chilli fruits. Plants are frequently exposed to various biotic and abiotic stresses and therefore have evolved a multi-layered system of defence mechanisms [1]. Defense strategies of plants against pathogens are several, including the production of antifungal chemicals, which are either pre-formed (i.e., already present in plant tissue in different amounts) or induced following infection (e.g., de novo synthesized phytoalexins) [2]. Phenolic phyto-anticipins that inhibit the growth of fungi may include simple phenols, phenolic acids, flavonols, and some isoflavones. Phytoalexins that are induced in response to fungal infection include isoflavonoids, pterocarpans, furocoumarins, flavans, stilbenes, phenanthrenes [3]. The accumulation of secondary metabolites especially phenolic compounds can restrict the spread of the pathogen by the formation of biopolymers in plants (e.g., lignin and callose). However, this type of response is only one part of the diverse layers of plant response to pathogen infection. Soluble as well as cell wall-bound phenolic compounds accumulate early after infection in many plant-pathogen systems in both susceptible and resistant interactions. Phenolic compounds can assist in preventing ROS damage by scavengers and protect cells from free radicals [4]. A number of phenols are regarded as pre-infection inhibitors, providing plants with a certain degree of basic resistance against pathogenic microorganisms [5]. External stimuli can modulate the synthesis of phenolic compounds and therefore change the chemical composition or quantities of phenolic compounds in the plants. External stimuli include microbial infections, UV light, mechanical wounding of the plant [6], as well as insecticides and herbicides [7]. Fungicides like, maneb, benomyl, and nabam induced the synthesis of hydroxyphaseollin in soybean [8]. Plant phytohormones such as abscisic acid, jasmonic acid, ethylene and salicylic acid (SA) are important components of different signalling pathways involved in plant defense [9]. Plants treated with zinc sulphate $10^{-5} \mathrm{mmol}$ and subsequently challenged with the Sclerotinia stem rot, caused maximum accumulation of tannic, gallic and chlorogenic acids after 24,48 and $72 \mathrm{~h}$, respectively [10]. In plants, flavonoids play an important role in biological processes. Beside their function as pigments in flowers and fruits, to attract pollinators and seed dispersers, flavonoids are involved in UV-scavenging, fertility and disease resistance [11]. Host plant resistance is considered as most practical, feasible and an economical method of plant disease management. Estimation of biochemical constituents helps in detecting their role in the resistance mechanism. Keeping in view the importance of the disease, the present study was carried out with the objective, evaluation of the effect of non-conventional chemicals and synthetic fungicide on biochemical characteristics of chilli against fruit rot pathogen Colletotrichum capsici for the management of the disease.

*Corresponding author: Neelam Geat, Division of Plant Pathology, Indian Agricultural Research Institute, New Delhi (110012), India, Tel: 01125841178; E-mail: nilugeat@gmail.com

Received December 05, 2015; Accepted January 09, 2016; Published January 13, 2016

Citation: Geat N, Singh D, Khirbat SK (2016) Effect of Non-conventional Chemicals and Synthetic Fungicide on Biochemical Characteristics of Chilli against Fruit Rot Pathogen Colletotrichum capsici. J Plant Pathol Microbiol 7: 328. doi:10.4172/2157-7471.1000328

Copyright: ( 2016 Geat N, et al. This is an open-access article distributed under the terms of the Creative Commons Attribution License, which permits unrestricted use, distribution, and reproduction in any medium, provided the original author and source are credited. 


\section{Materials and Methods}

A pot experiment was conducted at Department of Plant Pathology, CCS, HAU, Hisar, Haryana, India during 2013-14. In this study, two different varieties Pusa Jwala (susceptible to Colletotrichum capsici) and Sadabahar (resistant to Colletotrichum capsici) of chilli (Capsicum annuum L.) were raised in February, 2013 at nursery level and transplanted the seedlings in first week of April. Furthermore, five nonconventional chemicals viz; salicylic acid, zinc sulphate, magnesium sulphate, indole acetic acid, indole butyric acid and and synthetic fungicide viz; carbendazim were sprayed on red fruits of both chilli varieties for biochemical analysis using three different concentrations $(0.2 \mathrm{mM}, 1 \mathrm{mM}$ and $5 \mathrm{mM})$. The red fruits ( 5 fruits on each plant) were then inoculated with standard spore suspension $\left(3 \times 10^{4}\right.$ spore $\left./ \mathrm{ml}\right)$ from 8 days old culture of Colletotrichum capsici by pin prick method after 24 hrs of chemicals spray. Culture of Colletotrichum capsici were maintained on PDA medium. The red fruits sprayed with water and pathogen alone served as control. After the inoculation of pathogen, red fruits were collected at 24 and $48 \mathrm{hrs}$ and various biochemical parameters viz; total phenol, flavonol, tannin and electrolyte leakage were studied.

\section{Extraction of phenolic compounds}

For extraction and estimation of total phenols, method of Swain and Hills [12] was adopted. Weighed $1 \mathrm{~g}$ of chilli red fruits and ground it with a mortar and pestle in $10 \mathrm{ml}$ of 80 per cent alcohol. The homogenate was centrifuged at $10,000 \mathrm{rpm}$ for 20 minutes. The clear supernatant was taken and residue was re-extracted thrice with $5 \mathrm{ml}$ of 80 per cent alcohol. The supernatant was pooled and final volume was made to $20 \mathrm{ml}$ with 80 per cent alcohol). This supernatant was used for estimation of total phenol, flavonol and tannin.

\section{Estimation of total phenols}

Took $1 \mathrm{ml}$ of the supernatant and evaporated it to dryness. Dissolve the residue in $1 \mathrm{ml}$ of distilled water. Then $3 \mathrm{ml}$ of distilled water was added to make final volume of $4 \mathrm{ml}$. After 3 minutes of addition of $0.5 \mathrm{ml}$ of Folin-Ciocalteau reagent, $2 \mathrm{ml}$ of saturated $\mathrm{Na}_{2} \mathrm{CO}_{3}$ solution was added to each tube. The contents were mixed thoroughly. Place the tube in boiling water for exactly one minute. Tubes were cooled and absorbance was recorded at $650 \mathrm{~nm}$ against a reagent blank. A standard curve prepared by using different concentrations of catechol (0-100 $\mu \mathrm{g} /$ $\mathrm{ml}$ ) was used to calculate total phenol content. Results were expressed as $\mathrm{mg}$ total phenol/1 $\mathrm{g}$ fresh fruit.

\section{Estimation of flavonol}

For estimation of flavonols the method of Swain and Hills [12] was adopted. Alcoholic extract $(1 \mathrm{ml})$ was taken in $25 \mathrm{ml}$ measuring flask and $5 \mathrm{ml}$ of vanillin reagent was added during $10-15$ seconds. The Flask was shaken in cold water bath to check the rise in temperature. Blank was also prepared with water and absorbance measured at 725 $\mathrm{nm}$. Flavonol content was calculated with the help of standard curve of tannic acid.

\section{Estimation of tannin}

Tannin was estimated in extracted samples by using Vanillin- $\mathrm{HCl}$ reagent [13]. For estimation of total tannin content $1 \mathrm{ml}$ extract was taken in $50 \mathrm{ml}$ tubes. Added $25 \mathrm{ml}$ of ethanol to each tube, swirled and mixed occasionally by swirling. After 20-28 hrs swirl and let settle. Pipette out $1 \mathrm{ml}$ of supernatant into each of the two tubes, $5 \mathrm{ml}$ of vanillin reagent were added in each tube, and the blank was prepared with Vanillin- $\mathrm{HCl}$ reagent. Absorbance was measured at $525 \mathrm{~nm}$, and the tannin content was calculated with the help of standard curve of tannic acid.

\section{Estimation of electrolytic leakage}

Electrolytic leakage was estimated by the method described by Mahadevan and Shridhar, [14]. Initially, $1 \mathrm{~g}$ red fruit of inoculated and uninoculated chilli variety (Pusa jwala and Sadabahar) were taken and fruit was cut into nearly equal pieces. These were immersed in $50 \mathrm{ml}$ of deionised water contained in $100 \mathrm{ml}$ conical flasks. The flasks were placed in shaker-cum-water bath at $37 \pm 1^{\circ} \mathrm{C}$ and shaken for $8 \mathrm{hrs}$ at 70 strokes/minute. Fruit material was then filtered and the conductance of the leachates was determined with a digital conductivity meter. Conductivity of the electrolytes was expressed as $\mu$ mhos.

\section{Results and Discussion}

\section{Total phenol}

Total phenol content was increased in resistant as well as susceptible variety when sprayed with non-conventional chemicals and fungicide followed by pathogen inoculation in all the concentration. The increase in phenol content was significantly higher in both the varieties along with pathogen when sprayed with salicylic acid followed by pathogen as compared to other non-conventional chemicals at both intervals. The increase in total phenol was more pronounced in resistant variety $(7.84$ $\mathrm{mg} / \mathrm{g}$ fresh weight) after $48 \mathrm{hrs}$, when sprayed with salicylic acid at 5 $\mathrm{mM}$ concentration. No significant difference was observed in salicylic acid and fungicide spray at $5 \mathrm{mM}$ concentration (Table 1).

The importance of phenolic compounds in disease resistance has been recognized since the off-quoted works of Walker [15,16] who demonstrated the protective role of preformed phenolics in onion against smudge pathogen Colletotrichum circinans. The resistant onion variety contains protocatechuic acid and catechol. These phenols are water soluble and diffuse from the dead cell layers of the seeds into the infection drop and due to their high toxicity against Colletotrichum circinans inhibit germination and penetration [17]. Some reports showed the enhancement in total phenol contents in response to both the test pathogen isolates of Ascochyta rabiei in resistant genotype $\mathrm{E}$ $100 \mathrm{Y}$ while it was decreased in susceptible genotype H 208 when subjected to inoculation at 2-10 days intervals [18]. In the present study the total phenol content was increased in resistant as well as susceptible variety when sprayed with non-conventional chemicals and followed by pathogen inoculation. The increase in phenol content was significantly higher in both the red fruits of the variety when sprayed with salicylic acid as compared to other non-conventional chemicals at both intervals. The increase in total phenol was more pronounced in resistant variety when sprayed with salicylic acid at $5 \mathrm{mM}$ concentration. No significant difference was observed in case of salicylic acid and fungicide followed by pathogen inoculation at $5 \mathrm{mM}$ concentration in both varieties. The total phenol content was increased when groundnut leaves were sprayed with salicylic acid $24 \mathrm{hrs}$ before pathogen inoculation [19].

\section{Flavonol}

Flavonol content was higher in uninoculated red fruits of susceptible variety $(1.50 \mathrm{mg} / \mathrm{g}$ fresh weight $)$ as compared to resistant $(1.37 \mathrm{mg} / \mathrm{g}$ fresh weight). There was increase in flavonol content when inoculated with non-conventional chemicals and fungicides followed by 24 and $48 \mathrm{hrs}$ after pathogen inoculation. The increase in flavonol content was non-significant between the time intervals (Table 2).

Previous reports showed that high concentrations of flavonoids and alkaloids in the infected plant make the plant resistant to sooty 
Citation: Geat N, Singh D, Khirbat SK (2016) Effect of Non-conventional Chemicals and Synthetic Fungicide on Biochemical Characteristics of Chilli against Fruit Rot Pathogen Colletotrichum capsici. J Plant Pathol Microbiol 7: 328. doi:10.4172/2157-7471.1000328

Page 3 of 5

\begin{tabular}{|c|c|c|c|c|c|c|c|}
\hline \multirow{3}{*}{ Chemicals } & \multirow{3}{*}{$\begin{array}{l}\text { Concentration } \\
(\mathrm{mM})\end{array}$} & \multirow{2}{*}{\multicolumn{2}{|c|}{$\begin{array}{c}\text { Pusa jwala } \\
\text { Intervals after pathogen inoculation }\end{array}$}} & \multirow{3}{*}{ Mean } & \multirow{2}{*}{\multicolumn{2}{|c|}{$\begin{array}{l}\text { Sadabahar } \\
\text { Intervals after pathogen inoculation }\end{array}$}} & \multirow{3}{*}{ Mean } \\
\hline & & & & & & & \\
\hline & & $24 \mathrm{~h}$ & \begin{tabular}{|l|l}
$\mathbf{4 8 ~ h}$ \\
\end{tabular} & & $24 \mathrm{~h}$ & $48 \mathrm{~h}$ & \\
\hline \multirow{3}{*}{ Salicylic acid } & 0.2 & 3.64 & 4.45 & 4.05 & 4.35 & 5.85 & 5.10 \\
\hline & 1 & 4.06 & 4.75 & 4.41 & 5.31 & 7.30 & 6.31 \\
\hline & 5 & 5.37 & 6.48 & 5.93 & 6.20 & 7.84 & 7.02 \\
\hline \multirow{3}{*}{ Zinc sulphate } & 0.2 & 2.97 & 3.42 & 3.20 & 4.15 & 5.45 & 4.80 \\
\hline & 1 & 3.42 & 3.85 & 3.64 & 4.39 & 5.65 & 5.02 \\
\hline & 5 & 4.06 & 4.22 & 4.14 & 4.95 & 5.70 & 5.33 \\
\hline \multirow{3}{*}{$\begin{array}{l}\text { Magnesium } \\
\text { sulphate }\end{array}$} & 0.2 & 2.61 & 3.24 & 2.93 & 3.95 & 5.35 & 4.65 \\
\hline & 1 & 2.93 & 3.70 & 3.32 & 4.10 & 5.45 & 4.78 \\
\hline & 5 & 3.10 & 3.96 & 3.53 & 4.25 & 5.85 & 5.05 \\
\hline \multirow{3}{*}{ Indole acetic acid } & 0.2 & 3.18 & 4.03 & 3.61 & 4.18 & 5.60 & 4.89 \\
\hline & 1 & 3.21 & 4.12 & 3.67 & 4.58 & 5.75 & 5.17 \\
\hline & 5 & 3.33 & 5.00 & 4.17 & 4.95 & 5.95 & 5.45 \\
\hline \multirow{3}{*}{ Indole butyric acid } & 0.2 & 3.60 & 4.25 & 3.93 & 4.25 & 5.84 & 5.05 \\
\hline & 1 & 3.80 & 4.65 & 4.23 & 4.35 & 5.98 & 5.17 \\
\hline & 5 & 4.25 & 4.95 & 4.60 & 4.60 & 6.05 & 5.33 \\
\hline \multirow{3}{*}{ Carbendazim } & 0.2 & 4.20 & 5.11 & 4.66 & 5.65 & 5.85 & 5.75 \\
\hline & 1 & 4.65 & 5.23 & 4.94 & 5.85 & 6.35 & 6.10 \\
\hline & 5 & 4.95 & 5.30 & 5.13 & 6.19 & 7.86 & 7.03 \\
\hline Water spray & - & 2.75 & 3.25 & 3.00 & 3.65 & 4.85 & 4.25 \\
\hline Pathogen spray & - & 3.00 & 4.15 & 3.58 & 4.05 & 5.25 & 4.65 \\
\hline C.D. $(p=0.05)$ & $\begin{array}{ll}\text { Varieties } & \text { Time } \\
\text { (A) } & \text { (B) } \\
0.06 & 0.05\end{array}$ & $\begin{array}{l}\text { Chemicals } \\
\text { (C) } \\
0.02\end{array}$ & $\begin{array}{l}\text { Concentration } \\
\text { (D) } 0.01\end{array}$ & $\begin{array}{r}(n \times D) \\
0.15\end{array}$ & & & \\
\hline
\end{tabular}

Table 1: Total phenol gradient ( $\mathrm{mg} / \mathrm{g}$ fresh weight) in the fruits of resistant (Sadabahar) and susceptible variety (Pusa jwala) of chilli in response to non-conventional chemicals followed by pathogen inoculation at different intervals.

\begin{tabular}{|c|c|c|c|c|c|c|c|}
\hline \multirow{3}{*}{ Chemicals } & \multirow{3}{*}{$\begin{array}{l}\text { Concentration } \\
(\mathrm{mM})\end{array}$} & \multirow{2}{*}{\multicolumn{2}{|c|}{$\begin{array}{l}\text { Pusa jwala } \\
\text { Intervals after pathogen inoculation }\end{array}$}} & \multirow{3}{*}{ Mean } & \multirow{2}{*}{\multicolumn{2}{|c|}{$\begin{array}{l}\text { Sadabahar } \\
\text { Intervals after pathogen inoculation }\end{array}$}} & \multirow{3}{*}{ Mean } \\
\hline & & & & & & & \\
\hline & & $24 \mathrm{~h}$ & $48 \mathrm{~h}$ & & $24 \mathrm{~h}$ & $48 \mathrm{~h}$ & \\
\hline \multirow{3}{*}{ Salicylic acid } & 0.2 & 1.53 & 1.63 & 1.58 & 1.63 & 1.65 & 1.64 \\
\hline & 1 & 1.90 & 2.05 & 1.97 & 2.03 & 2.05 & 2.04 \\
\hline & 5 & 2.50 & 2.58 & 2.54 & 2.65 & 2.67 & 2.65 \\
\hline \multirow{3}{*}{ Zinc sulphate } & 0.2 & 1.22 & 1.31 & 1.27 & 1.47 & 1.50 & 1.48 \\
\hline & 1 & 1.58 & 1.61 & 1.59 & 1.74 & 1.79 & 1.76 \\
\hline & 5 & 2.06 & 2.10 & 2.08 & 2.15 & 2.19 & 2.17 \\
\hline \multirow{3}{*}{$\begin{array}{l}\text { Magnesium } \\
\text { sulphate }\end{array}$} & 0.2 & 1.17 & 1.20 & 1.18 & 1.37 & 1.39 & 1.37 \\
\hline & 1 & 1.54 & 1.63 & 1.58 & 1.62 & 1.64 & 1.63 \\
\hline & 5 & 1.97 & 2.02 & 2.00 & 1.90 & 1.98 & 1.94 \\
\hline \multirow{3}{*}{ Indole acetic acid } & 0.2 & 1.41 & 1.47 & 1.44 & 1.54 & 1.56 & 1.55 \\
\hline & 1 & 1.77 & 1.83 & 1.80 & 1.83 & 1.84 & 1.84 \\
\hline & 5 & 1.98 & 2.01 & 2.00 & 2.15 & 2.22 & 2.18 \\
\hline \multirow{3}{*}{ Indole butyric acid } & 0.2 & 1.47 & 1.56 & 1.51 & 1.58 & 1.60 & 1.59 \\
\hline & 1 & 1.81 & 2.01 & 1.91 & 1.92 & 1.94 & 1.93 \\
\hline & 5 & 2.01 & 2.14 & 2.08 & 2.33 & 2.40 & 2.36 \\
\hline \multirow{3}{*}{ Carbendazim } & 0.2 & 1.67 & 1.71 & 1.69 & 1.42 & 1.51 & 1.46 \\
\hline & 1 & 1.51 & 1.59 & 1.55 & 1.58 & 1.76 & 1.67 \\
\hline & 5 & 1.65 & 1.76 & 1.70 & 1.81 & 1.95 & 1.88 \\
\hline Water spray & - & 1.42 & 1.50 & 1.46 & 1.25 & 1.37 & 1.31 \\
\hline Pathogen spray & - & 1.43 & 1.49 & 1.46 & 1.46 & 1.69 & 1.58 \\
\hline C.D. $(p=0.05)$ & $\begin{array}{lr}\text { Varieties } & \text { Time } \\
(\mathrm{A}) & \text { (B) } \\
0.01 & \mathrm{NS}\end{array}$ & $\begin{array}{l}\text { Chemicals } \\
\text { (C) } \\
0.02\end{array}$ & $\begin{array}{r}\text { Concentration } \\
\qquad(\mathrm{D}) \\
0.03\end{array}$ & Interact & $\times B \times C \times D)$ & & \\
\hline
\end{tabular}

Table 2: Total flavonol gradient (mg/g fresh weight) in the fruits of resistant (Sadabahar) and susceptible variety (Pusa jwala) of chilli in response to non-conventional chemicals followed by pathogen inoculation at different intervals.

mold of olive leaves [20]. The present investigation failed to throw any significant light on its role in fruit rot resistance in chilli. The flavonol content was more in red fruits of susceptible variety before inoculation. There was increase in flavonol content when inoculated with non-conventional chemicals and fungicide followed by 24 and 48 hrs after pathogen inoculation. The increase in flavonol content was non-significant between time intervals. The flavonol level on challenge inoculation indicated the insignificant role in disease resistance. 
Citation: Geat N, Singh D, Khirbat SK (2016) Effect of Non-conventional Chemicals and Synthetic Fungicide on Biochemical Characteristics of Chilli against Fruit Rot Pathogen Colletotrichum capsici. J Plant Pathol Microbiol 7: 328. doi:10.4172/2157-7471.1000328

Page 4 of 5

\section{Tannin}

Total tannin content was higher in resistant $(3.71 \mathrm{mg} / \mathrm{g}$ fresh weight) as well as susceptible $(3.09 \mathrm{mg} / \mathrm{g}$ fresh weight) varieties after inoculation than uninoculated varieties. Increase was significantly higher in both the varieties when sprayed with salicylic acid followed by pathogen inoculation than other non-conventional chemicals and fungicide (Table 3). Tannin has been implicated sometimes in disease resistance and sometimes in disease susceptibility. Plants treated

\begin{tabular}{|c|c|c|c|c|c|c|c|}
\hline \multirow{3}{*}{ Chemicals } & \multirow{3}{*}{$\begin{array}{l}\text { Concentration } \\
(\mathrm{mM})\end{array}$} & \multirow{2}{*}{\multicolumn{2}{|c|}{$\begin{array}{c}\text { Pusa jwala } \\
\text { Intervals after pathogen inoculation }\end{array}$}} & \multirow{3}{*}{ Mean } & \multirow{2}{*}{\multicolumn{2}{|c|}{$\begin{array}{l}\text { Sadabahar } \\
\text { Intervals after pathogen inoculation }\end{array}$}} & \multirow{3}{*}{ Mean } \\
\hline & & & & & & & \\
\hline & & $24 \mathrm{~h}$ & $48 \mathrm{~h}$ & & $24 \mathrm{~h}$ & $48 \mathrm{~h}$ & \\
\hline \multirow{3}{*}{ Salicylic acid } & 0.2 & 1.82 & 2.22 & 2.02 & 2.51 & 2.90 & 2.70 \\
\hline & 1 & 2.22 & 2.55 & 2.38 & 2.87 & 2.99 & 2.93 \\
\hline & 5 & 2.69 & 3.09 & 2.89 & 3.05 & 3.71 & 3.38 \\
\hline \multirow{3}{*}{ Zinc sulphate } & 0.2 & 0.94 & 1.16 & 1.05 & 1.27 & 1.64 & 1.45 \\
\hline & 1 & 1.05 & 1.49 & 1.27 & 1.75 & 1.94 & 1.85 \\
\hline & 5 & 1.35 & 1.96 & 1.65 & 1.93 & 2.27 & 2.10 \\
\hline \multirow{3}{*}{$\begin{array}{l}\text { Magnesium } \\
\text { sulphate }\end{array}$} & 0.2 & 0.80 & 0.98 & 0.89 & 0.98 & 1.16 & 1.07 \\
\hline & 1 & 0.98 & 1.31 & 1.15 & 1.35 & 1.45 & 1.40 \\
\hline & 5 & 1.16 & 1.55 & 1.36 & 1.53 & 1.94 & 1.74 \\
\hline \multirow{3}{*}{ Indole acetic acid } & 0.2 & 1.16 & 1.46 & 1.31 & 1.64 & 1.85 & 1.75 \\
\hline & 1 & 1.31 & 1.76 & 1.54 & 1.96 & 2.19 & 2.07 \\
\hline & 5 & 1.96 & 2.29 & 2.12 & 2.40 & 2.87 & 2.64 \\
\hline \multirow{3}{*}{ Indole butyric acid } & 0.2 & 1.57 & 2.01 & 1.79 & 2.29 & 2.39 & 2.34 \\
\hline & 1 & 1.82 & 2.34 & 2.08 & 2.25 & 2.64 & 2.45 \\
\hline & 5 & 2.07 & 2.69 & 2.38 & 2.87 & 3.38 & 3.12 \\
\hline \multirow{3}{*}{ Carbendazim } & 0.2 & 1.05 & 1.60 & 1.33 & 1.38 & 1.82 & 1.60 \\
\hline & 1 & 1.49 & 1.93 & 1.71 & 2.47 & 2.51 & 2.49 \\
\hline & 5 & 1.71 & 2.58 & 2.15 & 2.73 & 2.98 & 2.86 \\
\hline Water spray & - & 0.80 & 1.02 & 0.91 & 1.24 & 1.38 & 1.31 \\
\hline Pathogen spray & - & 1.75 & \begin{tabular}{|r|r} 
& 2.33 \\
\end{tabular} & 2.04 & 2.22 & 2.69 & 2.46 \\
\hline C.D. $(p=0.05)$ & $\begin{array}{l}\text { Varieties } \\
\text { (A) } \\
0.04\end{array}$ & $\begin{array}{c}\text { Chemicals } \\
\text { (C) } \\
0.07\end{array}$ & $\begin{array}{l}\text { Concentration } \\
\text { (D) } \\
0.05\end{array}$ & tion & $B \times C \times D)$ & & \\
\hline
\end{tabular}

Table 3: Total tannin gradient (mg/g fresh weight) in the fruits of resistant (Sadabahar) and susceptible variety (Pusa jwala) of chilli in response to non-conventiona chemicals followed by pathogen inoculation at different intervals.

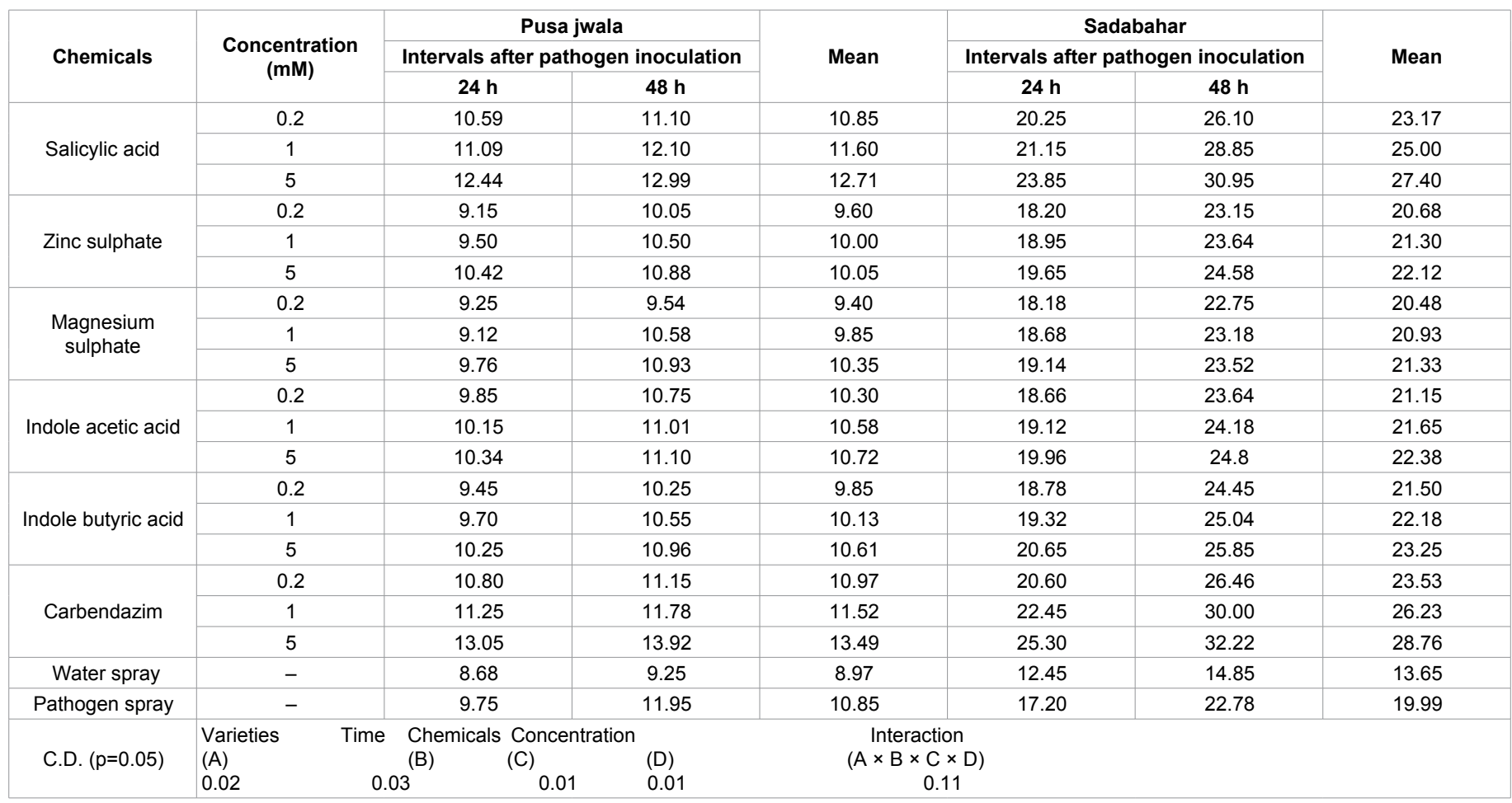

Table 4: Electrolytic leakage ( $\mu$ mhos/g fresh weight) in the fruits of resistant (Sadabahar) and susceptible variety (Pusa jwala) of chilli in response to non-conventional chemicals followed by pathogen inoculation at different intervals. 
Citation: Geat N, Singh D, Khirbat SK (2016) Effect of Non-conventional Chemicals and Synthetic Fungicide on Biochemical Characteristics of Chilli against Fruit Rot Pathogen Colletotrichum capsici. J Plant Pathol Microbiol 7: 328. doi:10.4172/2157-7471.1000328

with zinc sulphate $10^{-5} \mathrm{mmol}$ and subsequently challenged with the Sclerotinia stem rot, caused maximum accumulation of tannic, gallic and chlorogenic acids after 24,48 and $72 \mathrm{~h}$, respectively [10]. In the present study the tannin was higher in resistant as well as susceptible variety upon inoculation with Colletotrichum capsici than control. Increase was significantly higher in both the varieties when sprayed with salicylic acid followed by pathogen inoculation than other nonconventional chemicals.

\section{Electrolyte leakage}

There was significant increase in the activity of electrolytes in resistant variety as compared to susceptible variety when sprayed with non-conventional and fungicide in all the concentration. Increase was more pronounced in resistant variety (30.95) at $5 \mathrm{mM}$ concentration when sprayed with salicylic acid as compared to susceptible one. The leakage of electrolyte was more when sprayed with fungicide as compared with salicylic acid $5 \mathrm{mM}$ concentration after $48 \mathrm{hrs}$ of pathogen inoculation (Table 4).

Change in membrane permeability is the first detectable event in the onset of disease caused by different pathogens. In the present studies, it was found that there was significant increase in the leakage of electrolytes in resistant variety as compared to susceptible variety. Increase was more pronounced in resistant variety as compared to susceptible one with salicylic acid spray at $5 \mathrm{mM}$ concentration. The leakage of electrolytes was more when sprayed with fungicide as compared with salicylic acid $5 \mathrm{mM}$ concentration after $48 \mathrm{hrs}$ of pathogen inoculation. Treatment of leaves of Cicer arietinum with Azoxystrobin resulted in electrolyte leakage as measured by increased electrical conductivity (EC). The increase in EC was pronounced with the increase in fungicide concentration and incubation period. The negative EC values obtained in the Difenoconazole treatment may be due to fast and efficient uptake of the fungicide from the ambient solution by the leaf tissue [21]. It is known that along with the electrolyte, leakage of phenol also takes place. One of the probable reason may be the phenol while in contact with oxidizing enzyme get converted into the quinines or higher molecular weight compound which block the cell membrane pore and then decreased the outward flow of electrolytes. Alternatively, the electrolytes themselves get depleted as a result of outward flow from the cells. [22] while assessing chickpea (Ascochyta rabiei) interaction reported significant increase in the activity of electrolytes after inoculation with both blight isolates in resistant and susceptible genotypes as compared to uninoculated control.

\section{Conclusion}

This biochemical study indicated that there was pronounced increase in total phenol and tannin content in resistant variety (Sadabahar) when sprayed with salicylic acid at $5 \mathrm{mM}$ concentration. The activity of electrolytes was more in resistant variety as compared to susceptible with salicyclic acid at $5 \mathrm{mM}$ concentration. However, there was no significant change in flavonol content after spraying with chemicals.

\section{Acknowledgements}

The first author sincerely acknowledges ICAR for the financial support in the form of Junior Research Fellowship for M.Sc. research programme. Thanks are also due to the Head and Guide for providing field and laboratory facilities at the Department of plant pathology, CCS HAU, Hisar during the course of this investigation.

\section{References}

1. Eckey-Kaltenbach H, Ernst D, Heller W, Sandermann Jr H (1993) Crossinduction of defensive phenylpropanoid pathways in parsley plants by ozone. ed.eds.) pp. 192-198.

2. Grayer RJ, Kokubun $T$ (2001) Plant-fungal interactions: the search for phytoalexins and other antifungal compounds from higher plants. Phytochemistry 56: 253-263.

3. Chérif M, Arfaoui A, Rhaiem A (2007) Phenolic compounds and their role in bio-control and resistance of chickpea to fungal pathogenic attacks. Tunisian Journal of Plant Protection 2: 7-21.

4. Torres MA, Jones JD, Dangl JL (2006) Reactive oxygen species signaling in response to pathogens. Plant Physiol 141: 373-378.

5. Satisha J, Doshi P, Adsule PG (2008) Influence of rootstocks on changing the pattern of phenolic compounds in Thompson seedless grapes and its relationship to the incidence of powdery mildew. Turkish Journal of Agriculture and Forestry 32: 1.

6. Matsuki M (1996) Regulation of plant phenolic synthesis: from biochemistry to ecology and evolution. Australian Journal of Botany 44: 613-634.

7. Daniel O, Meier MS, Schlatter J, Frischknecht P (1999) Selected phenolic compounds in cultivated plants: ecologic functions, health implications, and modulation by pesticides. Environmental Health Perspectives pp. 107-109.

8. Lydon J, Duke S (1993) The role of pesticides on host allelopathy and their effects on allelopathic compounds. Pesticide interactions in crop production: beneficial and deleterious effects. CRC, Boca Raton pp. 37-56.

9. War AR, Paulraj MG, War MY, Ignacimuthu S (2011) Role of salicylic acid in induction of plant defense system in chickpea (Cicer arietinum L.). Plant Signal Behav 6: 1787-1792.

10. Sarma B, Basha SA, Singh D, Singh U (2007) Use of non-conventional chemicals as an alternative approach to protect chickpea (Cicer arietinum) from Sclerotinia stem rot. Crop Protection 26: 1042-1048.

11. Schijlen EG, Ric de Vos CH, van Tunen AJ, Bovy AG (2004) Modification of flavonoid biosynthesis in crop plants. Phytochemistry 65: 2631-2648.

12. Swain T, Hillis W (1959) The phenolic constituents of Prunus domestica I.The quantitative analysis of phenolic constituents. Journal of the Science of Food and Agriculture 10: 63-68.

13. Burns RE (1971) Method for estimation of tannin in grain sorghum. Agronomy Journal 63: 511-512

14. Mahadevan A, Sridhar R (1982) Methods in physiological plant pathology.

15. Walker J (1923) Disease resistance to onion smudge. Journal of Agricultural Research 24.

16. Walker JC (1926) Botrytis neck rots of onions. US Government Printing Office.

17. Walker J, Link KP (1935) Toxicity of phenolic compounds to certain onion bulb parasites. Botanical Gazette pp. 468-484.

18. Khirbat S, Jalali B (1997) Physiological changes in chickpea due to ascochyta blight inoculation. Annals of Agri Biology Research 2: 133-136.

19. Meena B, Marimuthu T, Velazhahan R (2001) Salicylic acid induces systemic resistance in groundnut against late leaf spot caused by Cercosporidium personatum. Journal of Mycology and Plant Pathology 31: 139-145.

20. Ilias F, Bensehaila S, Medjdoub K, El Haci I, Gaouar-Benyelles N (2015) The role of phenolic compounds in the defense of sooty mold of olive leaves (Olea europea L.). African Journal of Microbiology Research 9: 1075-1081.

21. Nithyameenakshi S, Jeyaramraja $P$, Manian $S$ (2006) Investigations on phytotoxicity of two new fungicides, azoxystrobin and difenoconazole. American Journal of Plant Physiology 1: 89-98.

22. Khirbat S, Jalali B (2000) Electrolyte leakage and carotenoid content in chickpea leaves in response to infection with Ascochyta rabiei. Indian Phytopathology 53: 35-37. 